\title{
7. Different governance for difference: the Bawinanga Aboriginal Corporation
}

\section{Jon Altman}

This chapter focuses on the organisational history and governance development of the Bawinanga Aboriginal Corporation (BAC) from its establishment in 1979 until late 2007. BAC is located in the Aboriginal township of Maningrida in north-central Arnhem Land in the Northern Territory (NT). It was incorporated under the Commonwealth Aboriginal Councils and Associations Act 1976 as an outstations resource organisation. Its original objects were to provide services to its members, most of whom resided at small dispersed outstation communities in the Maningrida hinterland of around $10,000 \mathrm{~km}^{2}$. BAC, however, has always been more than just a resource agency for outstations. From its formation it has also administered a significant Aboriginal arts centre, Maningrida Arts and Culture (MAC), and so has provided services to artists both at outstations and at Maningrida. Even before its formal incorporation, key Aboriginal and non-Aboriginal personnel subsequently associated with BAC were engaged in advocating for land rights, outstation development and ultimately regional Aboriginal self-determination. BAC has always been a progressive organisation advocating for appropriate forms of development for its membership.

$\mathrm{BAC}^{\prime}$ s organisational life path can be seen in three phases. The first, which dates from the early 1970s to 1989, is as an outstation resource agency (ORA) and Aboriginal arts centre. The second, from 1989, saw the transformation of BAC as it evolved into a major Community Development Employment Projects (CDEP) organisation. The start of the third phase, which saw BAC expand into a regional development agency, is more difficult to precisely demarcate. This phase probably dates from 1996, when BAC established its first Maningrida-based business and was subsequently recognised by the Australian Government as an organisation with sufficient capacity to administer major programs.

The Maningrida region is culturally heterogeneous and administratively complex. Maningrida was established as a government settlement some 50 years ago, during an era when the assimilation of Aboriginal people into mainstream Australian society was official colonial settler state policy. From 1957, there were political tensions between local Aboriginal land owners and other Aboriginal groups; and between Aboriginal people and white administrators operating with very different social norms and notions of accountability, and with highly differentiated political power. While BAC was established in the immediate post-colonial period, when self-determination became official government policy, it has had to operate in a complex intercultural environment. While ostensibly 
BAC has a key role brokering on behalf of its membership with the Australian state, it also faces the complex challenge of mediating the diverse interests of its membership. These diverse Aboriginal interests are dynamic, transforming, and difficult to unambiguously demarcate - they are influenced by a complex system of land ownership, language (or multi-language), personal and group identity, shifting locational and family affiliations, and associated local political alliances.

The principal aim of this chapter is to explain how BAC has managed to effectively and simultaneously manage governance tensions between Aboriginal and non-Aboriginal social norms and within its Aboriginal membership. This explanation is provided by tracing BAC's organisational history and its transformative, intercultural form of governance. The analytic explication seeks to identify some of the factors that have been critical to the governance and development success of BAC in effectively managing the tensions between western market-based and Indigenous kin-based social norms.

While history matters greatly in the BAC story, the focus here is primarily on the years since 1999. This is the time when formal governance emerged as a growing organisational issue. It is also a period in which the broader national Indigenous affairs environment has undergone some major transformations, with the abolition of the Aboriginal and Torres Strait Islander Commission (ATSIC) in 2004 and the sudden declaration of the NT National Emergency Response in June 2007. These recent events provide an interesting book-ending of the nearly 30 year organisational existence of BAC.

The corporation was established to meet the emerging needs of the Maningrida region's growing outstations population. Today, those same needs exist, but the policy proposals announced in 2007 to abolish the two programs that have provided core funding to BAC by 30 June 2008 placed its future at considerable risk. This is a timely juncture to consider the vulnerability of a structurally dependent Aboriginal organisation (in what Rowse [2002] has termed the Indigenous sector') to the vagaries of policy change, irrespective of impressive performance, robust governance or the aspirations of membership. This in turn raises broader questions about the asymmetry of power relations in Australian society, the recent intolerance of the neoliberal state to cultural difference, and the extent that community governance and advocacy really matter for vulnerable Indigenous organisations.

\section{A brief regional, social and historical background}

The governance of Indigenous discrete communities is significantly influenced by their particular colonial histories and subsequent decolonisation experiences. The history of the Maningrida region needs some explication if we are to understand the background and operations of BAC. There is quite a significant 
literature about this region with key publications including Hiatt (1965), Meehan (1982), Altman (1987) and Gurmanamana, Hiatt and McKenzie (2002).

The Maningrida region is loosely demarcated by a region bounded by the Liverpool River to the west, the Glyde River to the east and the Arnhem Land escarpment to the south. It is estimated to cover $10,000 \mathrm{~km}^{2}$ of tropical savanna. The regional population estimated in the 2006 Census is about 3,000, 162 being non-Aboriginal. ${ }^{1}$ The region is extraordinarily linguistically diverse, with at least 10 distinct Aboriginal languages still in common usage in the region, besides Aboriginal English. And regional diversity is not just limited to languages. There are also variations evident in local and social organisation, religion and ritual, customary economies, art styles, and so on.

The region is extremely remote, even by Australian standards, located $500 \mathrm{~km}$ east of Darwin and with only seasonal overland access. It is for this reason in part that it was colonised by the Australian state relatively late (Altman and Hinkson 2007). The region is in the middle of the vast Arnhem Land Aboriginal Reserve with entry limited by the Aboriginals Ordinance No. 9 (Cth) from 1918 onwards. A trading post was established in Maningrida in 1949-50 by the Native Affairs Branch of the NT Administration - to repatriate and keep Aboriginal people from the region out of Darwin-but then abandoned. In 1957, a government settlement was established at Maningrida, and only in 1963 was a bush track 'blazed' between Oenpelli (also known as Gunbalanya) and Maningrida by staff of the now renamed Welfare Branch of the NT Administration. ${ }^{2}$ Some people from outlying inland areas only moved to Maningrida at that time.

Significant effort and public funding was expended on the development of Maningrida from 1957. Under the policy framework of assimilation, the aim was to centralise, sedentarise and 'civilise' or Europeanise Aboriginal people in the region, a state project that proved extremely costly and unsuccessful, and which was abandoned in 1972. This failure of assimilation is an aspect of policy history that current neo-conservative writing conveniently overlooks (see e.g., Hughes 2007). Even before 1972, there was a people's movement in the region that saw families return to live in small decentralised groups on their traditional lands. In doing so, they were rejecting the particular form of 'modernisation' offered at externally-controlled settlements and missions, and moving to live remotely

\footnotetext{
1 The 2006 census enumerated 1904 Aboriginal and 156 non-Aboriginal people at Maningrida; 355 Aboriginal and six non-Aboriginal people at outstations; and a total regional population of 2345 , including those who did not state their identity. An estimated resident population for Maningrida and outstations is not provided by the Australian Bureau of Statistics, but it is estimated that Territory-wide there is an undercount of 19 per cent. Assuming that this undercount is consistent across the NT (which it is not), the regional Aboriginal population can be factored up by 1.19 to just fewer than 3000, of which about five per cent is non-Indigenous. It is possible that the undercount was actually greater in the Maningrida region than elsewhere in the NT because of the large hinterland and dispersal of the population to outstations and seasonal camps during the dry, when census enumeration is undertaken. 2 Before then, Maningrida was supplied by sea.
} 
with minimal support from the state. A conservative reading of history erroneously sees this decentralisation as just a product of the permissive and progressive shift to self-determination and land rights from 1972, whereas this social movement preceded these policy developments (Coombs 1974). Decentralisation certainly accelerated as policy settings changed, but it may have happened anyhow owing to the failure of centralisation and the associated social tensions and extreme poverty experienced in Maningrida.

\section{Fig. 7.1 Maningrida regional map}

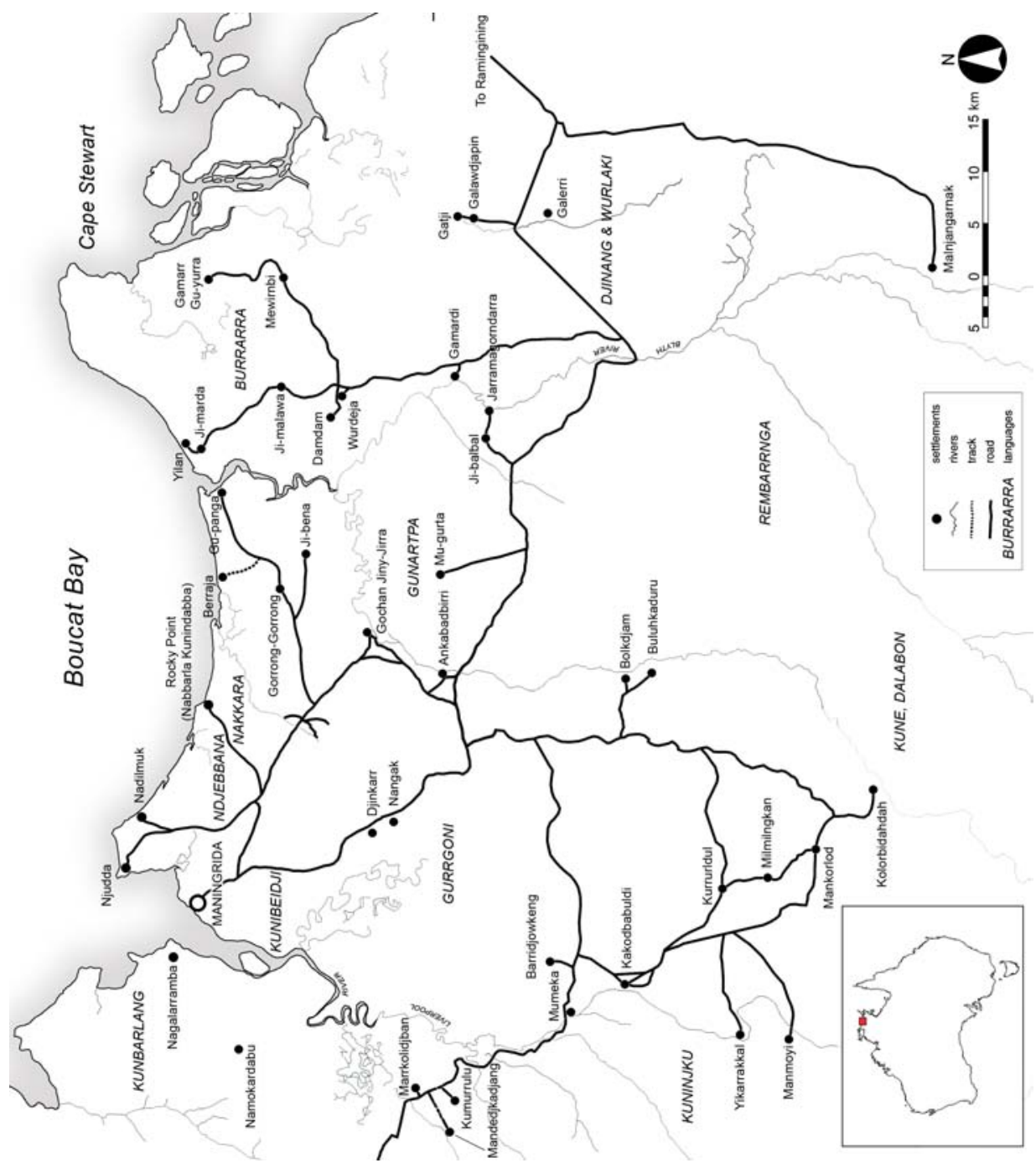

Elements of colonial discourse and associated ambiguities that remain today are notions of decentralisation and the term 'outstation', both of which are rarely used by Aboriginal people. Even the more modern terms, such as 'homeland 
communities' and 'return to country' (Blanchard 1987), suggest that people left, voluntarily or involuntarily. An outstation conjures up a notion of an outpost from a settlement, whereas in reality, for the residents it is just a locality on the land that they either own or to which they have rights of residence owing to kinship or other customary criteria. Local Aboriginal people just use the place name for an outstation locality as in Fig. 7.1, although when talking to outsiders generally prefer the term 'outstation' that I use here.

Maningrida was established because it was an administratively convenient locality near a fresh water spring at the mouth of the Liverpool River, on the land of the Dukurrdji clan. It is now, some 50 years on, a well-established township where the Dukurrdji land owners are greatly outnumbered. Outstations, by contrast, are small and generally located near perennial sources of fresh water and other natural resources. Outstations now have infrastructure and telecommunications that facilitate articulation with the wider administrative world, while maintaining a physical distance from Maningrida. Outstations have changed little in function from the 1970s (see Council for Aboriginal Affairs (CAA) 1976). Today, an outstation locality generally consists of a few houses, a source of year-round reticulated water, a Telstra pay phone, a bush airstrip or helipad, seasonal road access, and sometimes a small school building, usually with a residence for a visiting teacher (see Altman 2006).

\section{Theory, methods and caveats}

There is a dominant theoretical supposition in the governance and development literature that good governance at the local level is imperative to poverty reduction and development more generally (Grindle 2004: 525). This proposition has been theoretically and empirically examined in the Harvard Project on American Indian Economic Development (Cornell and Kalt 1995), which has greatly influenced the Indigenous Community Governance Project (ICGP) in Australia.

From 1979, I have observed and then collaborated with BAC, but it was nearly 20 years on before I belatedly started asking the fundamental question, does governance really matter? Initially, I did this in a very partial way, focusing only on parts of BAC's operations. In 1998, I examined BAC as an ORA as part of a national review (Altman, Gillespie and Palmer 1999); in 1999, I produced a business development plan for Maningrida Arts and Culture (Altman 1999); and in 2000, I collaborated in a review of BAC as a CDEP organisation, but again focusing somewhat narrowly on the efficacy of this program (Altman and Johnson 2000).

My specific interest and direct involvement in BAC governance issues escalated in 2003 when I was engaged as an advisory consultant by Dan Gillespie of Tallegalla Pty Ltd in the development of the first strategic plan for BAC for the 
triennium 2004-06 (Tallegalla 2003). In 1999, as part of a consultancy to revise BAC's constitution, Gillespie (1999) had undertaken a diagnostic assessment of the organisation, which identified the need for a strategic plan as a high priority. This planning exercise was undertaken in 2003 and involved consultation with members of BAC, its Executive Committee, senior management and staff-it was explicitly sought and funded by ATSIC.

Despite Gillespie's (1999) earlier recommendation, strategic planning was externally driven. This reflected a certain organisational antipathy to formal planning and governance processes. There was a degree of organisational comfort with a historically stable status quo based largely on relations of trust between senior managers and members, and an organisational preference for informal processes. An analysis in 2003 of BAC's strategic weaknesses and threats identified governance as a major planning and operational issue (Altman and Gillespie 2003: 10). In the subsequent strategic plan, governance was elevated to the first 'Key Result Area' priority (Tallegalla 2003: 12). The strategic planning exercise was a turning point for BAC, in belatedly recognising active engagement with formal notions of governance as an organisational priority.

The research reported here is mainly informed by visits made to Maningrida between 2005 and 2007 under the research umbrella of the ICGP. The field research visits have been quite short, so in a sense only provide governance 'snapshots'. But owing to long-standing research relationships, BAC's senior managers and executive have been welcoming, transparent and inclusive. For example, I was invited to all formal meetings of the executive that occurred during my visits, and was also able to participate, sometimes on a daily basis, in the informal meetings of members of BAC executive in the 'smoko' room, sometimes with BAC senior staff, sometimes without.

Participant observation in the smoko room critically influenced my views about BAC governance when I was finally able to recognise it as an 'informal' institution. The smoko room is a part of the BAC office, but has no windows, only security mesh so that passers-by can see in and chat with those inside - it is very transparent. It is popular with both Aboriginal staff and the executive because it is a place where one can relax, have a cup of tea, and, importantly, smoke. There is a great deal of communication and social interaction, both between members of the executive and between the executive and other BAC members and their families, constantly occurring in this place. This happens in various communication styles, in a mix of the numerous local languages and in Aboriginal English. Social interactions in the smoko room are often theatrical, humorous and extremely difficult to follow. But they constitute an institution where the rules of the BAC game (to paraphrase Leach, Mearns and Scoones 1999) are debated and explicated. Governance encompasses notions like power sharing, making legitimate decisions about actions and resources, sharing 
information, accountability, making policy, and having rules and norms that determine such actions. This all happens informally in the smoko room.

The smoko room is an informal institution (to be differentiated from the more formal executive meetings held to accord with western incorporations law) because distinctly Indigenous social norms and codes of behaviour dominate in this setting. This institution is of crucial importance to BAC's sound governance. This is especially the case when local Aboriginal elites, with ascribed power based on seniority and customary authority, interact with the 'neo-elites' whose power is mandated through modernising processes (see Collman 1988). A long time ago, Bagshaw (1977: 28) referred to the latter as balanda marringi (in the Burarra language), literally 'understanding whiteman' to be contrasted with gala marringi, the non-cognisant. ${ }^{3}$ I labour this point to highlight that the smoko room provides opportunity for these two groups to interact productively. It is also noteworthy that outsider snapshots of such Aboriginal governance processes can be inadequate if they do not observe such informal institutions at work, although they can be difficult to interpret.

Finally, it is important that my earlier interests in the activities and governance of BAC are clearly stated to transparently address the issue of potential conflict of interest. While I am recognised by BAC as a long-term 'friend', both the governing committee and senior management have historically allowed me unfettered access to material and have been open to research findings, even when critical. Another source of potential conflict of interest is my early residence in 1979-81 at an outstation called Mumeka, whose residents are members of the Kuninjku language community. Arguably (and this argument has been made by local Aboriginal people themselves), my take on BAC has always been a little over-influenced by a Kuninjku-centric view of the regional polity. I do not deny this possibility, but note that this old allegiance has abated somewhat as more and more research is undertaken with individuals from other language communities.

\section{A potted history of BAC's organisational evolution}

In the early 1970s as the outstations movement gathered momentum in central Arnhem Land, Aboriginal people were increasingly empowered to return to live on their traditional lands. The exodus from Maningrida was one of the most significant from the $\mathrm{NT}^{\prime}$ 's centralised Aboriginal settlements in population terms (see CAA 1976; Meehan 1982; Altman 1987). Government policy at that time supported decentralisation and this in turn required organisational support, especially in the delivery of basic services: fortnightly delivery of social security

\footnotetext{
${ }^{3}$ In recent communications, Bagshaw notes that the grammatically more correct terms in Burarra would be marngi balanda gun-nika rom aburr-ni and gala marrngi balanda gun-nika aburr-ni (pers. comm. 5 November 2007).
} 
cheques and commodities from the Maningrida store; assistance with basic external communications and the marketing of arts and crafts; and assistance with establishing rudimentary water reticulation in some situations. In those days, there were no standard western housing or ablution facilities at outstations.

Initially, this basic support was provided by the Department of Aboriginal Affairs, then by the Maningrida Progress Association, and then from 1976 by a branch of the Maningrida town council, called the Maningrida Outstation Resource Centre (see Gillespie, Cooke and Bond 1977). The resource centre was staffed by three non-indigenous men-Dan Gillespie, Peter Cooke and David Bond - assisted by a number of local men, some now deceased. Gillespie and Cooke had lived in the region for some years and were strong advocates for land rights, the outstations movement and Aboriginal self-determination. At that time, a political dispute emerged within the Maningrida Council between these white staff of the resource centre dubbed 'progressives' and other 'conservative' senior staff of the Maningrida Council. While this division was between balandas (non-Aboriginal people) and was along party political lines, it also reflected a tension in the region between the township and outstations, and between those adhering to the old 'assimilation' regime that still had considerable influence in the township and those committed to the new 'self-determination' policy introduced in 1972.

The political rift within the Maningrida Council came to a head in 1978 when, on the advice of the Department of Aboriginal Affairs, the Minister for Aboriginal Affairs, Ian Viner, ordered the sacking of key members of both factions and the revocation of their permits, an action that he was empowered to make as Maningrida township was not yet part of the Arnhem Land Aboriginal Land Trust. Subsequently, Gillespie, Cooke and Bond challenged the Minister's decision in the NT Supreme Court and his decision was judged illegal and overturned. It is noteworthy that there was strong community support for Gillespie, Cooke and Bond, and after the decision Cooke and Bond went back to again work to support outstations. An insightful account of this episode is provided by MacCallum (1978).

As a consequence of this episode, there was recognition by the Department of Aboriginal Affairs that a separate incorporated entity was needed to support outstations, and so BAC was established as a purpose built ORA during 1979 by its inaugural executive officer, Ian Hughes. BAC was incorporated under the Aboriginal Councils and Associations Act 1976 (Cth) in October 1979. The name Bawinanga was a composite of three language names from the hinterland, as then spelt: Barada (Burrarra) in the east, Gunwinggu (Kuninjku) to the west, and Rembarranga (Rembarrnga) to the south.

BAC operated successfully as an outstation service delivery organisation, both from the perspectives of funding agencies and its membership, from 1979 to the 
late 1980s. It was mainly funded by the Commonwealth Department of Aboriginal Affairs because, under a Memorandum of Understanding between the Commonwealth and a self-governing NT, the Commonwealth agreed to meet this responsibility (see Altman 2006). BAC gained a sound reputation as an efficient service delivery agency that was effective in supporting a population in the bush. Some of this status was linked to BAC also running Maningrida Arts and Culture (then Crafts) as a high profile Aboriginal arts centre that operated for both township and outstations artists. This was an important service, which provided BAC with some experience in running a cultural enterprise that made a significant difference to local people's livelihoods. From late 1980, David Bond took over as chief executive officer of BAC and remained with the organisation in that capacity until 2005; Peter Cooke ran Maningrida Arts and Crafts from 1979 to 1982, and subsequently retained strong personal and professional links with BAC.

From 1989, BAC expanded to also become an organisation that administered the CDEP scheme. The growth of BAC as a CDEP organisation has been covered in some detail elsewhere (Altman and Johnson 2000). This was an historic moment that marked a fundamental change in the nature of BAC for a number of reasons. First, while its early CDEP engagement was limited and mainly oriented to provide income support to outstation residents, its corporate robustness meant that this role expanded rapidly. This was especially the case after 1997 when BAC was invited by ATSIC to take over the Maningrida Council's CDEP scheme participants, owing to Council problems with maladministration at that time. Running CDEP meant that BAC had to rapidly expand its administrative and project management capacity, especially when it took over administering township based participants. Second, CDEP provided BAC with discretionary administrative and capital resources that it incrementally invested in developing a number of business and service arms. As a consequence of both these developments, BAC attained a far more visible Maningrida profile. Its earlier reputation as a best practice resource agency was now matched by a high reputation as a CDEP organisation, with associated external bureaucratic and political support.

From the late 1990s, about a decade after it gained access to the CDEP scheme, BAC entered another phase as a regional development agency. This phase is less easy to demarcate because it was linked to a gradual expansion of the organisation, which was largely overseen by a senior project officer, Ian Munro, appointed in 1991. Munro subsequently became BAC's deputy Chief Executive Officer (CEO) and from August 2005 its CEO. An analysis of BAC's consolidated financial accounts shows fairly marked increase in organisational turnover in the late 1990s, including in the administration of some significant grants for housing and infrastructure development at outstations, as well as a steady increase in the proportion of total income from trading activities (as distinct 
from CDEP grants from ATSIC). Organisational scale appears to have taken BAC onto a new level after its income exceeded \$10 million in 1997-98 and then expanded by another 50 per cent by 1999-2000.

The fundamental changes in organisation were recognised in 1999 with a modification of its constitution to provide greater emphasis not just on service delivery functions, but also to support Aboriginal cultural priorities, promotion of the management and sustainable use of Aboriginal-owned lands and resources, the welfare of its members, and business opportunities and economic independence.

Recently, BAC (2005a: 4) defined its mission in accord with its constitution in the following terms:

At the regional level we act as a force for the political integration and representation of the interests of over 100 regional land owning groups [members of patrilineal clans] of our members ...

As a service delivery agency BAC provides cultural and natural resource management programs, essential municipal and social services and labour market and economic development opportunities to its members in Maningrida and surrounding outstation communities.

The maintenance of land, language(s) and culture, the sustainable use of natural resources and the creation of viable enterprises employing Aboriginal people are central themes in all of BAC's activities.

Its mission statement demonstrates that BAC recognises its evolution into an organisation that serves members living in both Maningrida and outstations, and often residing flexibly between the township and various locations in the hinterland. This in turn makes its goal of acting as a force for political integration highly problematic, as the basis, authority and contexts for such a role are largely undefined, and the political interests of its membership are highly variable.

Even at an organisational level, BAC is diverse and complex for an Aboriginal entity as Fig. 7.2 illustrates. BAC has 20 formal business and service arms, with many combining the provision of services with a focus on commercial objectives and economic development possibilities.

A quick summary of BAC's published annual reports and audited financial statements for the last three years, 2004-05 to 2006-07, indicates that BAC employs over 500 CDEP participants - making it one of the country's largest CDEP organisations - and engages over 50 mainly non-Aboriginal salaried staff. Its turnover exceeds $\$ 25$ million per annum, with well over 50 per cent generated from trading income and the balance coming from a number of external grants, the most significant being for the operation of CDEP (see BAC 2005a, 2005b, 2006a, 2006b, 2007a, 2007b). 
Fig. 7.2 BAC organisational structure and business units

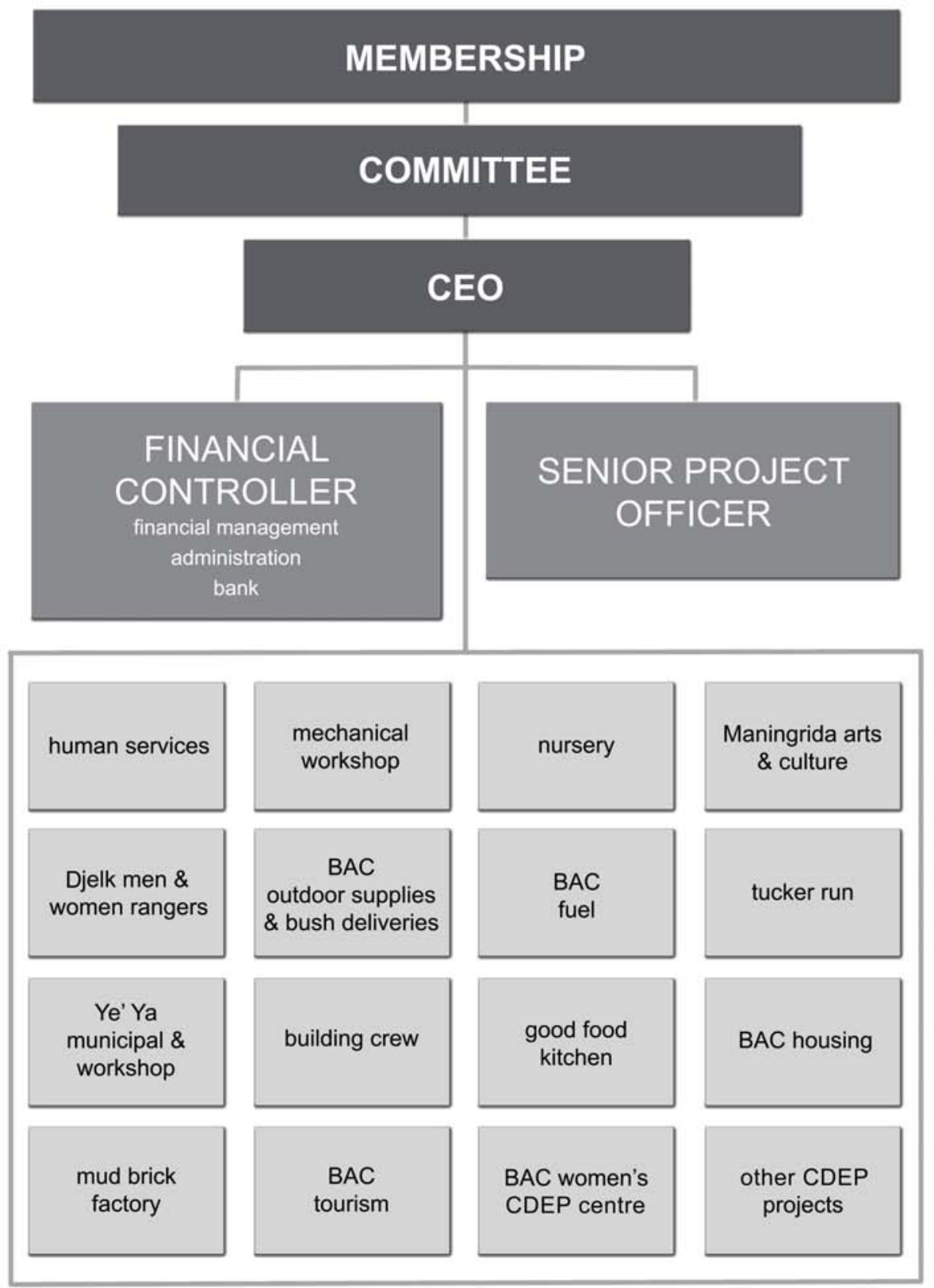

Source: Fogarty and Paterson 2007 


\section{Governance challenges}

BAC is a distinctive form of organisation that is intercultural: its organisational governance has to accommodate both western legal requirements and Indigenous social norms and external and internal accountability. In BAC's case, this governance interculturality is further complicated by the scale of the organisation, its history and its transformations over time, from a focused ORA to a mixed and more diverse organisation that also operates as a CDEP organisation and development agency. These complexities are further complicated again by the extraordinary cultural and linguistic diversity of its Indigenous constituency, by differences between the needs and aspirations of members who reside in town and country, and by long-standing territorial disputes (some of which had their genesis in the 1970s) with other Maningrida organisations. Many of these governance challenges and tensions are not unique to BAC. In this section, I focus on just a few of a myriad of governance challenges that BAC faces.

A first-order issue for BAC is the challenges that its all-Aboriginal executive face. This executive is elected by secret ballot at the annual general meeting, with the chairman being the nominated candidate who attracts the most votes. There is invariably a change of chairman from one year to the next and regular turnover in the composition of the executive. This makes executive decision making - which varies from the mundane to the multi-million dollar - difficult. This diversity of business is not unusual for committee-run organisations. For example, the executive has to be heavily involved in setting rules for CDEP, the dominant every day business, as well as in making investment decisions in relation to enterprises, and decisions about forms of new grant funding to be sought and new projects to pursue.

Two key challenges emerge here. First, the level of expertise needed to understand and oversee the operations of this complex conglomerate (see Fig. 7.2) is significant. In a community like Maningrida there is a relatively small pool of Aboriginal people who have the requisite educational qualifications and understanding of business and corporate governance to undertake this task. Arguably, this is an indictment of the Maningrida education system, but also of the lack of opportunity for on-the-job education and training at BAC given its organisational longevity. The few who have such skills face pressures to participate on other boards, placing them in actual or potential conflict of interest and under considerable workload pressures. As BAC's constitution requires an annual spill of executive positions, it is unusual for any executive members to be consistently re-elected. This, as noted later, reflects the aspirations of members to share both the benefits and responsibilities of office among numerous regional interest groups. Consequently, new executive members need to be familiarised with corporate decision making processes on an annual basis and there is limited 
growth of capacity and ongoing executive expertise over time. Board training and induction takes time and the legal requirements facing members are onerous.

This in turn means that senior management has far greater knowledge about the running of BAC than the executive. In BAC's case, the divergence between the Aboriginal executive and the non-Aboriginal management expertise has been exacerbated by high turnover of executive membership and low turnover of senior management: BAC has only had three chief executive officers since 1979. Historically, this has resulted in a degree of executive apathy in actively engaging in organisational governance and BAC being vulnerable to the external perception that it is only governed by senior management rather than the Aboriginal executive. BAC's organisational complexity and the past reluctance of the executive to be actively involved in governance also pose a major challenge to management in finding the right balance between executive and member consultation, and a focus on implementation and action. In the past this resulted in too much governance by management, something that is in the process of changing.

BAC is incorporated under Australian law and so has requirements to comply with western, formal modes of governance as set out in incorporations statute. As a general rule, incorporations law requires that members of the executive operate impartially without vested interest and to meet the objectives of the corporation for the benefit of its membership. Gerritsen and Straton (2007: 166) refer to this western incorporations requirement as a 'weberian rationality of impersonal distribution'. Such modes of governance are very different from Aboriginal modes of governance that prioritise kin-based obligations and sectional interests. In the BAC case, these sectional interests are diverse and fluid, comprising members of one's household or extended kinship group, or members of one's language community or totemic cluster, or outstation co-residents. Aboriginal social norms see pressure continually applied to executive members to respond to demands of particular sectional interests.

There is an ongoing tension between senior managers, who more readily ascribe to western modes of governance and are highly aware of external accountability requirements, and Aboriginal executive members, who have variable understandings of external accountability, but are acutely aware and constantly reminded of internal accountability to the sectional interests and the Aboriginal priorities that they represent. Finding the right balance between corporate compliance and appropriate responsiveness to member priorities is a continual governance challenge. This challenge is exacerbated if non-Indigenous staff do not understand Indigenous kin-based social norms and fundamentally appreciate the nature of Aboriginal connections to, and responsibilities for, country. ${ }^{4}$

${ }^{4}$ Understanding the actual content, not just the kin-based form, of local Aboriginal activities and priorities can be very difficult for non-Aboriginal staff. It is for this reason that Aboriginal people 
Choosing which governance approach to emphasise implicates a process that Bagshaw (1977: 27) referred to as 'jural selectivity'. While BAC's objects are broadly defined to allow compliance with Aboriginal priorities, like ceremonial participation, there is an ongoing tension in making the resource allocation between competing priorities, while complying with external bureaucratic and internal membership accountability.

Within BAC's membership and generally within the elected executive, there is a mix of elites: those who enjoy status on the basis of Aboriginal customary criteria and those who gain status on the basis of western knowledge, Bagshaw's 'balanda marringi'. The poor outcomes from the Maningrida education system mean that there are relatively few with the requisite English literacy to be members of the neo-elite. While this relatively small cadre is now actively involved in organisational governance, as noted above a number are simultaneously members of several Maningrida-based (and external) organisations. Historically, BAC has under-invested in corporate governance training for its executive, in part because of high executive turnover and in part because suitable governance training has not been locally available. This in turn resulted in member apathy and disinterest in what was often (erroneously) viewed as 'balanda business', because of the way the organisation had been structured and run in the past.

Invariably, the BAC executive includes a mix of the customary elite and the more western-familiar neo-elite. Informal processes see cross-cultural tensions between western and Indigenous modes of governance being constantly played out, often in executive committee meetings or in the less formal 'smoko room' context described earlier. Western modes of governance require strict adherence to corporations law and external accountability, at least in principle. ${ }^{5}$ The BAC executive neo-elites partially understand this, while Indigenous modes of governance require accountability to immediate family, broader kinship networks, language communities, ritual allies, co-residents and a myriad of other obligations with which executive members are encumbered. On occasion, an executive member belongs to both elites, and on other occasions elites and neo-elites form alliances in executive decision making. ${ }^{6}$

Organisational metamorphosis has presented BAC with new governance challenges. BAC's original raison d'etre was as an outstations support agency,

\footnotetext{
consistently seek to bridge this cultural gulf by inviting key balandas onto their country and into ceremonies.

5 I say 'in principle' because of the historically high rate of corporate non-compliance (and associated potential for fraud and embezzlement) that has bedeviled Aboriginal organisations, especially in very remote localities.

6 This essentially heuristic distinction between elites and neo-elites overstates the relative roles and statuses of the two categories. The very use of the term neo-elite is a heuristic categorisation that is potentially problematic as it is contextually constituted in relation to both balandas and Aboriginal people, 'countrymen'.
} 
but as noted elsewhere (Altman and Johnson 2000), its success first as a CDEP organisation and then as a development agency has provided more and more employment opportunities to its membership in Maningrida. Five-yearly census data indicate some drift of outstation residents into Maningrida over time, and while the reasons for this re-centralisation are complex, BAC's success is certainly one contributing factor.

This in turn has generated a new set of governance challenges. For example, BAC increasingly needs to maintain good patronage relations with the Dukurrdji traditional owners of Maningrida on whose lands its growing numbers of enterprises are located. This challenge has been addressed by the payment of lease rentals. Ultimately, BAC's success may offer too much opportunity for its membership in Maningrida (where all enterprises are located) rather than in the bush - a centralisation chain in-migration may result as kinship and sociality draw in the relatives of those finding opportunity in town. The logical consequence of this process is the abandonment and undermining of the culturally differentiated outstation communities in favour of a single culturally homogeneous (in relative terms) Maningrida population, whose younger members will become increasingly attenuated from their own lands and traditions. This will increasingly require BAC members to have multiple allegiances to both BAC and other Maningrida organisations that provide housing and other services. This creates challenges, as such multiple allegiances, mixed with notions of egalitarianism and risk minimisation, can create some ambivalence about BAC's regional dominance. In interview, two members of multiple boards emphasised to me that they did not want BAC to get 'too big'. It is also contrary to the original aims of the outstations movement.

From the outstations perspective, BAC has clearly become less of a resource agency, although it remains supportive of outstation needs. Outstation residents for their part have loosened their identity links with BAC alone and now also patronise other Maningrida organisations. The issue of servicing outstations in the Maningrida region is becoming increasingly complex, especially in the context of discussions about the amalgamation of townships and outstations into regional authority 'shires' (see D. Smith this volume, Chapter 4), and the proposed withdrawal of Commonwealth support of outstations from 1 July 2008. Any potential to resolve such issues appears to have been placed in temporary abeyance by the unfolding of dramatic 'national emergency' policy events in June 2007 discussed further below.

\section{Adaptively managing governance tensions}

The critical focus of my research is on understanding how western (incorporated) and customary (kin-based) forms of governance have been balanced in the operations of BAC. At one level, there has clearly been a successful mediation of these two quite different governance approaches. This is evidenced by the 
longevity of BAC, its growth and its success. At another level, historically there has been ready deferral to non-Aboriginal management, at least until recent times, which might suggest abrogation of governance responsibilities. What is remarkable about the BAC case is how these identified governance tensions have been astutely accommodated over a long period of time, while the organisation has experienced impressive growth and performance. In this section, I focus more specifically on the period since 2005 and what I have observed.

As noted earlier, the rapid growth of BAC in the 1990s was not matched by sufficient investment in organisational development. Between 2005 and 2007, there has been a rapid increase in focus on formal governance issues and a growing membership participation in governance. Historically, BAC management had been a little reluctant to embrace formal governance capacity building for its membership in part, because there was some reluctance to tamper with an organisational model that was working. A number of factors challenged and ultimately changed this view, including: external review and active participation in strategic planning in 2003; a change of organisational leadership in 2005; and a willingness by the executive and senior management to participate in the ICGP from 2005. A parallel process of governance training within the broader Maningrida community, sponsored by the Office of the Registrar of Aboriginal Corporations (ORAC) and delivered by the Maningrida JET Centre, a registered training organisation, also highlighted BAC's deficiencies in this area and provided some opportunity for governance training.

The new CEO, while a member of the senior management team since 1991, has embraced a greater focus on formal governance and has encouraged greater executive participation in the overall decision making for BAC. The strategy to change the governance balance to ensure greater membership participation has gained momentum. From 2004, BAC senior management moved to systematically address organisational deficiencies highlighted during strategic planning and incorporated in an action plan. In particular, executive committee members have been paid sitting fees and are expected to attend all meetings; the executive are involved more actively in agenda setting; more detailed records of meetings are maintained; and a number of members have participated in governance training. A survey of senior managers of four Maningrida-based organisations undertaken in mid 2005 suggested that they had all observed benefits from this governance training by the initial cohort of trainees - it provided participants with some understanding of corporate governance and financial management issues. Unfortunately, this training has only been provided on a sporadic basis owing to high staff turnover at the training centre, and in 2007 this training program was suspended.

Overall, in formal governance terms, BAC has adopted a far more transparent organisational culture in recent years: it has published annual reports of activities 
since 1999-2000, developed an Induction Manual (Johnson 2004), and has provided cross-cultural training for its non-Indigenous staff since 2004. There is no doubt that at a formal level BAC is regarded highly by ORAC, and in 2004-05 it rated special mention as a best practice Indigenous organisation (ORAC 2006: 37). BAC's formal processes are sound, financial audits are invariably unqualified, and the overall financial performance of the organisation is probably without parallel in a remote Indigenous community context.

What is equally important is to understand how intercultural checks and balances have been maintained, or how the apparent incommensurability between western and customary social norms have been mediated. This has occurred in three interdependent ways.

First, the annually elected executive comprises between 11 and 15 representatives affiliated with different outstations and language groups. Turnover of executive members ensures that there is no dominance by one section of the regional membership and this is recognised as beneficial to the entire membership. The executive is invariably made up of members of the elite and the neo-elite, and in executive meetings and through informal institutions such as meetings in the 'smoko' room, consensus is reached on key policies and decisions like the allocation of new housing. It is not uncommon for non-executive members to attend such meetings as observers, in accord with customary decision making processes.

The position of chairman is important as this is a salaried position that also provides access to a highly valued chairman's vehicle (when one is available). This prestigious position is invariably rotated on an annual basis, even though it is based on a secret ballot and is generally shared equitably between a number of language communities. In July 2006, the incumbent chairman identified the rapid turnover of his position as a potential problem for BAC and indicated a desire to possibly seek re-election, but this did not eventuate.

Second, there is careful negotiation of the tensions between customary obligations and legal compliance between non-Indigenous senior managers and members of the Indigenous executive. Much of BAC's corporate success and sound governance can be sheeted home to the stability of its non-Indigenous senior management and seamless succession. Effectively, after the first executive officer established BAC in 1979-80, there have been only two more: one from 1980 to 2005, and the next from September 2005 (who was appointed after 14 years with the organisation since 1991). Such continuity and succession is extraordinarily important, especially in a corporate environment where the Indigenous executive is only appointed for a period of 12 months at a time. BAC's organisational history and culture has ensured that senior managers have been appropriately attuned to the aspirations of BAC's membership. Importantly, as BAC's organisational scale and capacities have grown, there have been sufficient numbers of senior 
managers to ensure checks and balances on management decision making. As noted earlier, BAC is not averse to extra-regional scrutiny and constructive criticism, much of which emanates from a healthy organisational engagement with external, at-arms-length, independent research bodies.

Third, BAC executive and senior managers in particular retain an open-door policy whereby individuals have good access to discuss personal, family and outstation issues and priorities. This approach makes an important contribution to ensuring that governance is transparent and facilitates early detection and correction of any policy errors or misallocations. While this open-door approach is demanding and often appears time inefficient, it is something BAC has made into a virtue. As a general rule, there is an expectation that senior staff are prepared to commit to this governance mechanism.

None of this is intended to suggest that BAC's operations are either tension or error free. From time to time, the social norms of customary governance take precedence and there have been disputes over unauthorised vehicle use and inappropriate use of order books, usually associated with ceremonial or funeral expenses. But as a general rule, these incidents are relatively rare; they are sometimes resolved by adapting existing procedures and usually by ensuring repayment of any outstanding advances. It is not unusual for the informal institution of public shaming to be invoked when excesses occur among members of the executive. Similarly, tensions can erupt between managers of business units, for they too need to compete for an equitable share of BAC resources. At times these can be mediated and resolved, at other times a manager may resign or be dismissed. The governance of an intercultural organisation like BAC is difficult and systems can break down. Over time, and especially in recent years, BAC has ensured that the fiscal bottom line is maintained, while enterprise innovation and associated risk is encouraged.

A critical, and at times highly problematic, challenge that has been highlighted is that long-term managerialism has probably inhibited Aboriginal executive decision making. It is too easy to highlight BAC's success and longevity as a 'business enterprise' and to overlook its lack of success in genuinely representing and empowering its Aboriginal membership. The particular form of governance that operates at BAC is intercultural and hybrid. To retain its historic success as an organisation it will need to be increasingly adaptive and creative as it continues to address the re-alignment challenges posed by its need to operate effectively between western and Aboriginal worlds.

\section{Recent external threats}

BAC has operated successfully for nearly 30 years in a remote and difficult context where governance is influenced by competing western and Indigenous 
social norms. It provides an exemplary case of how such competing social norms can be negotiated and managed.

Yet in the last three years since the abolition of ATSIC in 2004, BAC faced a series of threats from the now defeated Howard Government. At one level, these threats were linked to changed Commonwealth policy emphases and BAC's dependence on Commonwealth programs, especially CDEP and the Community Housing and Infrastructure Program (CHIP), which funds municipal services for outstations. At another level, these threats were highly political, with federal politicians and bureaucrats seeking to determine, in accord with the ideological fashion of the day, what was best for BAC and its membership even if this was in direct opposition to the aspirations of BAC's elected executive and members. Elsewhere, I have termed this approach 'remote managerialism' (Altman 2005a).

There are at least two paradoxes apparent in the Commonwealth's approach since 2005. First, despite the dominant rationale peddled by the Australian Government that ATSIC was ineffective in delivering support to remote Indigenous communities, BAC's relations with ATSIC were robust and constructive. Indeed, in large measure it was ATSIC that encouraged and funded the processes whereby BAC embraced greater emphases on formal governance and strategic and succession planning. Just as these requirements were all being implemented and as my governance research began in 2005, relations between the Australian Government and BAC soured. This is paradoxical because as the central terms of Indigenous affairs policy swung to mutual obligation and shared responsibility, BAC and its successful CDEP operations and robust governance should have been viewed as a flagship example of achievement. Instead, the complex issue of mainstreaming, with its multiple meanings, has loomed large. This placed BAC at loggerheads with some powerful federal agencies, especially the Department of Employment and Workplace Relations (DEWR), which administered CDEP from 2004.

In 2005 and 2006 these strained relations mainly focused on divergent interpretations about the CDEP scheme's objectives: DEWR, as an employment agency, unilaterally redefined it as a program to transition participants to mainstream employment, while BAC remained focused on its historical intent to provide a mix of community development, employment creation, enterprise subsidy and income support.

This tension resulted in what was locally termed 'the CDEP wars', which ended in a stalemate in 2005 and 2006 because BAC acquiesced to sign externally imposed and unrealistic performance targets (see Altman 2005a). At the heart of this dispute were radically different views about the appropriate economic future for BAC's membership. The unrealistic view from Canberra was that mainstream employment, so called 'proper jobs', should be the long-term goal for all in the Maningrida region. BAC's objects, on the other hand, emphasise a different 
notion of development that is realistic and grounded and incorporates the high degree of flexibility that matches its members' aspirations - BAC has quite proactively adopted the 'hybrid economy' model (Altman 2001, 2005b) as encompassing its approach.

A syndrome marked by unnecessary tension seems to pervade relations between the bureaucracy and successful Aboriginal organisations, which goes beyond the current neoliberal hegemony. On the one hand, the bureaucracy relies on organisations like BAC to deliver the limited successes that have been achieved in Indigenous development in the last three decades. On the other hand, there is a palpable feeling of enmity toward successes like BAC at many levels of the bureaucracy. Success seems to attract criticism, increased scrutiny, and cynicism rather than praise and championing.

The announcement of the NT National Emergency Response and its associated measures by the Howard Government on 21 June 2007 constituted the greatest external threat to date to BAC's existence. These measures, enshrined in legislation in August 2007, provided the Australian Government legal instruments to strip BAC of its considerable fixed assets, while an externally-appointed bureaucrat, the Government Business Manager, was given absolute authority over democratically-elected executives like BAC's. Furthermore, as part of this emergency intervention, on 23 July 2007 the Australian Government announced that it would abolish the CDEP scheme throughout the NT (Hinkson 2007). BAC was informed in late 2007 that its CDEP support, which totalled just on $\$ 9$ million in 2006-07 (BAC 2007a: 29-31), would cease from March 2008. Its CHIP municipal funding of $\$ 400,000$ in 2006-07, which funds outstations support, would end on 30 June 2008. However, with a change of government on 24 November 2007 with a commitment to retain CDEP, this decision has now been reversed, although the CHIP municipal funding decision still stands. But in a Memorandum of Understanding signed between the Australian and the NT Governments in September 2007, \$20 million has been provided to underwrite the CHIP municipal funding for outstations, which BAC may well access in the future.

It is clear that without its considerable asset base, without funding for outstations support, and without a CDEP workforce of 550 and associated administrative resourcing, BAC would cease to exist as the significant regional development agency it has become. BAC's $(2007 \mathrm{a}, 2007 \mathrm{~b})$ most recent audited financial statement and annual report indicate that it is a profitable $\$ 27$ million per annum organisation. All this was to be jeopardised by the Australian Government's emergency intervention and new draconian laws. However, the change of government appears to have given BAC a reprieve, at least in the immediate term. 


\section{Governance for difference: analytic explication}

There is a considerable literature in Australia that highlights the ambiguity embedded in the notion of an Indigenous jurisdiction (Collman 1988; Rowse 1992, 2007; Sullivan 1996) and how the very notion of Aboriginal self-determination is often bounded by the legal requirements of western incorporations law. There is a dominant perception of incongruity between western and Aboriginal notions of governance. Yet what I argue here is that an organisation in the Indigenous sector is successfully engaging with both western and Aboriginal notions of governance via a particular form of interculturality. In this section, I briefly engage with two alternate views about governance in Maningrida, before providing my own analytical explication for why BAC has succeeded for nearly three decades.

Bagshaw (1977) analysed local government in Maningrida. Bagshaw's focus was on the Maningrida Council at the time when the outstation resource centre was one of its branches. Bagshaw (1977: 69) observed a degree of 'cross-cultural incongruity' between European economic-based and Aboriginal kin-oriented governance. Ultimately, he observed that European political forms and objectives were imposed on Aboriginal social life and that this took away any discretionary power from Aboriginal councillors. This dominance by European management resulted in Aboriginal people feeling politically impotent and generally disinterested in what was perceived of as 'balanda business'. At the same time, he noted that local Aboriginal people, who in relative terms understood European ways, practised what he termed 'jural selectivity' (1977: 27) as a means of coping with the ambiguities inherent in post-colonial township living. Jural selectivity involved choosing between traditional Aboriginal law and European law to cope with any given social situation. As a Nakkara informant put it to Bagshaw: 'now we have two ways ... angugalia [Aboriginal] and balanda [European] to fix our problems'. Bagshaw's was an early expression of the notion that was later termed interculturality, which can be understood as the complex processural manifestations of difference and inter-influence in situations of transformation (Hinkson and Smith 2005: 160).

Recently, and again referring to Maningrida (but no particular organisation), Gerritsen and Straton (2007: 166) highlight an apparent incongruence between what they term 'the weberian rationality of impersonal distribution' that dominates western governance and Indigenous kin-based competitiveness. They suggest that policy makers provide funding to Aboriginal organisations with the mistaken belief that Aboriginal social norms ensure egalitarian sharing. Their perspective recognises a mix of 'traditional culture' and 'western power and logic' in Maningrida, but nevertheless focuses only on intra-Aboriginal tensions in heterogeneous communities marked by hierarchy, divisions and competition that precludes the likelihood of social cooperation. Gerritsen and Straton's (2007) 
analysis can be juxtaposed with Bagshaw's. For Bagshaw, state intervention and control resulted in Aboriginal participation being crowded out by the domination of white management, while white management does not even figure in Gerritsen and Straton's analysis.

Writing about central Australia and using a Foucauldian framework, Batty (2005) focuses on the effective working relationships that have emerged between Aboriginal and non-Aboriginal people involved in the state project of self-determination. In his analysis, Batty highlights that these partnerships develop into sites of administrative and cultural mediation that accommodate the aspirations of both Aboriginal people and the state. Batty (2005: 220) suggests that one of the unintended consequences of the policy of self-determination was the formation of a 'more or less permanent class of white advisers whose position and effectiveness depended almost entirely on partnerships with Aboriginal people'. ${ }^{7}$ Elsewhere (Altman 2005b: 129), I have broadly concurred with Batty's partnership framework, but construe it a little differently in the BAC case. Here there are a series of partnerships: between white management and Aboriginal executive; within the senior management team, to provide the checks and balances that will militate against possible excesses often associated with monopoly management; and within the elected executive, which needs to constantly negotiate a degree of accommodation between diverse Aboriginal township and regional interest groups.

The analysis undertaken here recognises the tension between kin-based and market-based (or indigenous and western) governance orders and traces how creative organisational adaptations have been made to address such apparent structural incongruity.

Part of the explanation of BAC's success is the long-term relationships that have formed between a small number of trusted senior white managers, who have stayed for long periods and have understood Aboriginal social norms based on kinship obligations, and constantly churning Aboriginal executives. The annual changes in the composition of executives have ensured that no one sectional interest in the Maningrida region has been politically dominant, while the longevity of white management has facilitated administrative and cultural mediation between western and customary social norms.

Another important element is the particular history and politics of the organisation. From the outset, BAC was established to support Aboriginal aspirations to live on their country, to gain access to state income support and to pursue market opportunities compatible with remote outstation living. The culture and associated governance of BAC has always been politically allied to

\footnotetext{
7 An alternative and possibly more accurate term here, also from central Australia, might be Collman's (1988) notion of 'mutual patronage'.
} 
a particular section of the regional population: outstation residents. The white staff of BAC (and its predecessor) championed Aboriginal self-determination and emphasised practical aspects of meeting such Aboriginal aspirations. From the outset, BAC has been structured to accommodate diverse Aboriginal aspirations and differences, the commercial and the cultural. BAC has also been a thoroughly intercultural organisation, accommodating from the outset both western and Aboriginal social norms, while providing space for effective management by trusted whites. The ability of Aboriginal people to retain key balandas for long periods of time is fundamental to its success.

BAC effectively facilitates livelihoods that are dependent on the customary or non-market sector, on state support, and on successful engagement with the market (see BAC 2007b). BAC also recognises that its members might participate in all three sectors of the hybrid economy and the interdependencies between these sectors that are mainly underwritten by the CDEP scheme. BAC delivers a local form of 'cultural match' that allows its membership to readily move between outstation and township living, while actively engaging in different forms of livelihood possibilities. Over time, BAC has evolved into a hybrid intercultural organisation (Altman and Cochrane 2003) whose objects and actions clearly recognise the highly flexible nature of local hybrid economies (Altman 2001). The parallels between this hybrid institutional framework and the hybrid economy are at the heart of BAC's success.

\section{A final reflection}

It would be nice to conclude this chapter here because it seems that, as an organisation, BAC has strengthened its institutional capacities and its adaptively managed governance is robust. In a policy sense, BAC is an important case because it is a clear success in a broader narrative of Indigenous failure dominant in recent years. Yet, as noted above, each of its core organisational components - outstations, CDEP and appropriate development that accords with local aspirations - are currently under threat from the NT intervention and the new state project of normalisation. Unfortunately, BAC has remained dependent on the state and hence it is highly vulnerable to changes both in policies and in laws. For nearly 30 years, BAC has provided its membership effective 'governance for difference', but this has been threatened in recent times by the Howard Government's attempts to impose 'governance for sameness'. The BAC case shows that it is possible to govern to meet both western and Aboriginal requirements - cross-cultural congruence is possible. However, if cultural difference is not tolerated by the state, then power asymmetry can undermine and ultimately destroy intercultural projects, irrespective of their success. Or can it?

In early 1978, just five years after self-determination became official Commonwealth policy, the federal Minister for Aboriginal Affairs in the Fraser 
Coalition Government intervened to revoke the permits of three non-Indigenous staff working for outstations, despite the protestations of local Aboriginal people. At that time, recourse to the Supreme Court of the NT was available to challenge the Minister's decision, which was judged illegal and overturned. These people were empowered by the Australian legal system to return to Maningrida.

As this chapter is being completed, BAC is a joint plaintiff (with Maningrida traditional owners Reggie Wurridjal and Joy Garlbin) in an action in the High Court of Australia, which is challenging the authority of the Commonwealth to seize its assets without just terms compensation and so to undermine its organisational viability. The Commonwealth has always been empowered to terminate BAC's access to the CDEP scheme, despite its obvious success in administering this program since 1989. The change of Federal Government on 24 November with an election commitment to retain the CDEP scheme will see a reversal in some recent destructive policy proposals and in BAC's fortunes. Ultimately, the demise or survival of BAC might always be determined by wider ideological and political processes. But it says a great deal for the robust intercultural governance of BAC that its membership, executive, management and staff have effectively taken the fight up to the Australian state during the last three years to fight for its survival, in the name of 'governance for difference'.

\section{Acknowledgements}

I would like to thank my very many Aboriginal and non-Aboriginal collaborators in Maningrida for their assistance and support over many years. There are just too many to name individually so I will just select Ian Munro, the CEO of BAC, and Peter Danaja, the BAC public officer, for special mention. In completing this chapter I thank Geoff Bagshaw, Mike Dillon, Bill Fogarty, Dan Gillespie, Melinda Hinkson, Will Sanders and two anonymous referees for incisive and challenging comments.

\section{References}

Altman, J. C. 1987. Hunter-Gatherers Today: An Aboriginal Economy in North Australia, Australian Institute of Aboriginal Studies, Canberra.

- 1999. Maningrida Arts and Culture: Business Development Plan 2000-2002, Unpublished report prepared for the Bawinanga Aboriginal Corporation, CAEPR, ANU, Canberra.

2001. 'Exploring sustainable development options on Aboriginal land: the hybrid economy in the 21 st Century', CAEPR Discussion Paper No. 226, CAEPR, ANU, Canberra.

-2005a. 'The governance of outstations in the Maningrida region, north-central Arnhem Land, and the challenges posed by the new 
arrangements', ICGP Occasional Paper No. 11, ICGP, CAEPR, ANU, Canberra.

2005b. 'Economic futures on Aboriginal land in remote and very remote Australia: hybrid economies and joint ventures', in D. Austin Broos and G. Macdonald (eds), Culture, Economy and Governance in Aboriginal Australia, University of Sydney Press, Sydney.

2006. 'In search of an outstations policy for Indigenous Australians', CAEPR Working Paper No. 34, CAEPR, ANU, Canberra.

and Johnson, V. 2000. 'CDEP in town and country Arnhem Land:

Bawinanga Aboriginal Corporation', CAEPR Discussion Paper No. 209, CAEPR, ANU, Canberra.

and Cochrane, M. 2003. 'Sustainable development in the Indigenous-owned savanna: innovative institutional design for cooperative wildlife management' , CAEPR Discussion Paper No. 247, CAEPR, ANU, Canberra.

and Gillespie, D. 2003. Strategic Planning Project for Bawinanga Aboriginal Corporation, Progress Report 1, Unpublished report to BAC, Tallegalla Consultants Pty Ltd, Brisbane.

— and Hinkson, M. 2007. 'Mobility and modernity in Arnhem Land: the social universe of Kuninjku trucks', Journal of Material Culture, 12 (2): 181-203.

— Gillespie, D. and Palmer, K. 1999. National Review of Resource Agencies Servicing Indigenous Communities, 1998, Aboriginal and Torres Strait Islander Commission, Canberra.

Blanchard, C.A. (Chairman) 1987. Return to Country: The Aboriginal homelands movement in Australia. Report of the House of Representatives Standing Committee on Aboriginal Affairs, Australian Government Publishing Service, Canberra.

Bawinanga Aboriginal Corporation (BAC) 2005a. Bawinanga Aboriginal Corporation, Annual Report 2004/05, BAC, Maningrida.

2005b. Bawinanga Aboriginal Corporation, Annual Financial Report 30 June 2005, BAC, Unpublished audited financial statements dated 21 September 2005.

2006a. Bawinanga Aboriginal Corporation, Annual Report 2005/06, BAC, Maningrida.

2006b. Bawinanga Aboriginal Corporation, Annual Financial Report 30 June 2006, BAC, Unpublished audited financial statements dated 29 August 2006. 
2007a. Bawinanga Aboriginal Corporation, Annual Financial Report 30 June 2007, BAC, Unpublished audited financial statements dated 25 September 2007.

2007b. Bawinanga Aboriginal Corporation, Annual Report 2006/07, BAC, Maningrida.

Bagshaw, G. 1977. Analysis of Local Government in a Multi-Clan Community, BA (Hons) Dissertation, Department of Anthropology, The University of Adelaide, Adelaide.

Batty, P. 2005. 'Private politics, public strategies: white advisers and their Aboriginal subjects', Oceania, 75 (3): 209-21.

Collman, J. 1988. Fringe Dwellers and Welfare: The Aboriginal Response to Bureaucracy, University of Queensland Press, St Lucia.

Coombs, H. C. 1974. 'Decentralisation trends among Aboriginal communities', Search, 5 (4): 135-43.

Cornell, S. and Kalt, J. P. 1995. 'Successful economic development and heterogeneity of government form on Aboriginal Indian reservations', PRS 95-4, Harvard Project on American Indian Economic Development, Malcolm Weiner Center for Social Policy, John F. Kennedy School of Government, Harvard University, Cambridge, MA.

Council for Aboriginal Affairs. 1976. Report on Arnhem Land, Commonwealth of Australia, Canberra.

Fogarty, B. and Paterson, M. 2007. Constructive Engagement: Impacts, Limitations and Possibilities During a National Emergency Intervention, Unpublished report for BAC, PIA Consultants, August 2007, available at

$<$ http://www.aph.gov.au/Senate/committee/legcon_ctte/nt_emergency/ submissions/sub03.pdf $>$.

Gerritsen, R. and Straton, A. 2007. 'Coping with a tragedy of the Australian Aboriginal common', in A. Smajgl and S. Larson (eds), Sustainable Resource Use: Institutional Dynamics and Economics, Earthscan, London.

Gillespie, D. 1999. Report to Bawinanga Aboriginal Corporation, Maningrida NT-Strategic Planning Issues for the Corporation, Unpublished report, Tallagella Pty Ltd.

- Cooke, P. and Bond, D. 1977. Maningrida Outstation Resource Centre, 1976-77 Annual Report, Milingimbi Literature Production Centre, Milingimbi.

Grindle, M. S. 2004. 'Good enough governance: poverty reduction and reform in developing countries', Governance: An International Journal of Policy, Administration and Institutions, 17 (4): 525-48. 
Gurrmanamana, F., Hiatt, L. and McKenzie, K. 2002. People of the Rivermouth: The Joborr Texts of Frank Gurrmanamana, Aboriginal Studies Press, Canberra.

Hiatt, L. R. 1965. Kinship and Conflict: A Study of an Aboriginal Community in Northern Arnhem Land, ANU Press, Canberra.

Hinkson, M. 2007. 'Introduction: in the name of the child', in J. C. Altman and M. Hinkson (eds), Coercive Reconciliation: Stabilise, Normalise and Exit Aboriginal Australia, Arena Publications, Melbourne.

— and Smith, B. 2005. 'Introduction: conceptual moves towards an intercultural analysis', Oceania , 75 (3): 157-66.

Hughes, H. 2007. Lands of Shame: Aboriginal and Torres Strait Islander 'Homelands' in Transition, Centre for Independent Studies, Sydney.

Johnson, V. 2004. Bawinanga Aboriginal Corporation Induction Manual: A Guide to Newly Arrived Staff, Unpublished report, BAC, Maningrida.

Leach, M., Mearns, R. and Scoones, I. 1999. 'Environmental entitlements: dynamics and institutions in community-based natural resource management', World Development, 2 (2): 225-47.

MacCallum, M. 1978. 'Viner muscles in on Maningrida', Nation Review, 27 April-3 May, p. 13.

Meehan, B. 1982. Shell Bed to Shell Midden, Australian Institute of Aboriginal Studies, Canberra.

Office of the Registrar of Aboriginal Corporations (ORAC). 2006. Yearbook 2004-05, ORAC, Canberra.

Rowse, T. 1992. Remote Possibilities: The Aboriginal Domain and the Administrative Imagination, North Australia Research Unit, ANU, Darwin.

2002. Indigenous Futures: Choice and Development for Aboriginal and Islander Australia, UNSW Press, Sydney.

2007. 'The national emergency and Indigenous jurisdictions', in J. C. Altman and M. Hinkson (eds), Coercive Reconciliation: Stabilise, Normalise and Exit Aboriginal Australia, Arena Publications, Melbourne.

Sullivan, P. 1996. All Free Men Now: Culture, Community and Politics in the Kimberley Region, Western Australia, Aboriginal Studies Press, Canberra.

Tallegalla Consultants Pty Ltd. 2003. Bawinanga Aboriginal Corporation, Strategic Plan 2004-2006, Unpublished report, Tallegalla Consultants Pty Ltd, Brisbane. 